\title{
THE GAS, ELECTRIC LIGHT, WATER AND STREET RAIL- WAY SERVICES IN NEW YORK CITY
}

\author{
By Robert Grier Monroe, \\ New York City.
}

New York is wholly dependent upon private corporations for gas and electric light. Private companies own and operate the surface and elevated railways and also operate the subway or underground railway as far as constructed. The water supply is owned and managed by the municipality.

\section{Water Supply.}

In 1832 the city undertook the construction of an aqueduct along the eastern bank of the Hudson to the Croton River, thirtythree miles to the north. The Croton watershed is the main source of New York's supply to-day. For the borough of Brooklyn part of the supply is taken from surface streams on the southern slope of Long Island and part drawn from wells. Water is sold by the city for domestic use to householders upon frontage rates-charges proportioned to the size of the dwelling and number of fixtures. To factories, hotels and commercial buildings water is sold by meter at ten cents a hundred cubic feet. Frontage rates come to about half the meter charge. Most of the water consumed is drawn for domestic use and most of the revenue is derived from the water sold for manufacturing and business purposes. The management of the water department is neither highly efficient nor marked with careful economy. It is a fair example of municipal operation. More than one hundred and twenty-five millions have been borrowed from time to time by the city for the construction of water works but less than two-thirds of the debt is now outstanding. Municipal bonds and corporate stock bear low rates of interest. The city has used what water was needed for public purposes and has sold enough to consumers to pay not only the running expenses and interest charges

(III) 
but also to furnish a fund to retire a portion of the bonds from year to year. The water revenue to-day provides for interest charges and running expenses and at the same time an annual surplus of between three and a half and four millions to be applied to a sinking fund or used for the general reduction of taxes.

Municipal ownership of the water supply is the fixed and settled policy of the city of New York. To meet increasing needs the city is about to enter upon an expenditure estimated to exceed one hundred and fifty millions for building aqueducts and developing the Catskill watershed as a new and greater source of supply. A commission of three appointed by the mayor upon nomination by the Chamber of Commerce, the Manufacturers' Association and the Board of Fire Underwriters will have charge of this public work, and there is every confidence that the public funds will be properly and honestly expended.

\section{Gas Service.}

The first gas light company in New York was incorporated in I823. In succeeding years one company after another was chartered on the theory that the public would benefit by competition. In I 884 the Consolidated Gas Company of New York was organized as a consolidation of six competing or independent gas companies. The consolidation was intended to embrace all the companies at that time selling gas in the then city of New York, but at the last moment one company had to be left out of the combination on account of a specific prohibition in its charter. The Consolidated Gas Company now owns the stock of the one company omitted at the time from the original combination, and also owns the stock of every company chartered since I884 to distribute illuminating gas on Manhattan Island. This ownership continues in spite of certain seemingly definite statutory prohibitions. In 1900 the Consolidated Gas Company took over the combination of electric companies in the borough of Manhattan.

In 1895 the gas companies in Brooklyn were brought together and the Brooklyn Union Gas Company organized. Brooklyn also has its electrical combination. For some years there has been no competition in the sale of light in the city of New York. The companies are all over-capitalized. That is, the issues of securities are out of all proportion to the intrinsic value of their plants. Stock 
and bonds have been issued on earning capacity based upon prices only to be sustained under a monopoly.

Notwithstanding the fact that successive combinations and consolidations have done away with any possibility of competition, the city charter continues to direct that all public lighting shall be let upon contract after public bidding and for a period not exceeding one year. In December, I902, the first year of Mayor Low's term of office, the usual advertisements were inserted asking for bids for lighting the streets and public buildings for the ensuing year-Ig03. In due course the regular bids were submitted by the monopoly, but instead of being promptly accepted as in previous years the prices named were examined and compared and the proposals finally rejected. The prices offered for open flame gas lamps ranged from $\$ 12$ per lamp per year to $\$ 25$ for the same class of light. The price in each district seemed to be fixed arbitrarily by the particular company there in control. In the past twenty years the cost of gas had dropped one-half, but the charge for city lamps remained unchanged. In certain instances the bids for 1903 corresponded exactly with the bids of I883. Two thousand candle power arc lamps were fixed at $\$ 146$ per lamp per year. The average price in other American cities is below ninety dollars.

Mayor Low took the position that the lighting companies as quasi-public corporations occupying public land were bound to render the service for which special privileges had been granted them, and could only exact reasonable compensation for such service. $\mathrm{He}$ further held that when a fair price for an article cannot be reached or even indicated by actual competition, the sum the city should pay should be settled after investigation into the cost of production and delivery of the commodity supplied. The monopoly, on the other hand, took the position that unless controlled by specific statutory enactment the seller alone had the right to fix the price. New York could take the goods or not; if she took them she must pay the price imposed. The issue involved disputed questions of both law and fact. The city insisted that gas and electricity be provided for lighting the streets and public buildings, but refused to make contracts on the monopoly's terms and declined to pay the monthly bills when presented, awaiting suit on quantum meruit for services rendered or for goods sold and delivered. There was talk of compromise, but the managers of the companies were men of great influence and 
wealth and accustomed to overcome any opposition. One company threatened to cut off the light, but an application to the court promptly stopped that performance. Mandamus proceedings were instituted to compel the city to accept the bids and execute contracts, but such proceedings were never pressed. No suits were brought during Mayor Low's administration to collect public lighting bills. His administration stood ready to join in a reasonable settlement, but at the same time it was prepared to protect the municipality-to inquire into the status of important franchises and even to question the legality of the monopoly itself.

Counsel for the companies saw that danger lurked in immediate litigation. There are times when it is well to sue and there are times when it is better to refrain from suit. Appeal to the courts was postponed to await the results of the coming election. New guardians of the public interests might be substituted for the men then in charge.

In the election of 1903 the public service corporations of New York City were able to throw sufficient strength to Tammany to elect Colonel McClellan and defeat Mr. Low. The victory of the lighting monopoly appeared at first to be complete, but the administration it had overcome at the polls had taken steps to safeguard the city's interest with a view to just such a contingency. Precautions had been carefully adopted to make future abandonment of the city's rights difficult and dangerous. In the first place, the Board of Estimate and Apportionment had put itself on record by the adoption of a clear and explicit report approving every step taken by the Department of Water Supply, Gas and Electricity with regard to public lighting for the year I903. The Board of Estimate and Apportionment, the real governing body of the city of New York, is composed of the mayor, comptroller, president of the Board of Aldermen and the presidents of the five boroughs, and several of these officials were to continue in office with the new administration. It was therefore impossible to have that body reverse itself without embarrassing individual members. Detailed departmental reports were published from time to time during the year 1903 informing the public fully as to what was done and why it had been done. Finally, before the end of Mr. Low's term of office, suits were instituted on behalf of the city against the Consolidated Telegraph and Electrical Subway Company and against 
the Empire City Subway Company for an accounting and forfeiture of their charters, and with the definite purpose of acquiring the electrical subway ducts. Control of the subway ducts is the basis of the electrical monopoly on Manhattan Island. The lighting trust only became complete when it covered both illuminants-gas and electricity.

In I886, when overhead wires were outlawed, the Consolidated Telegraph and Electrical Subway Company was formed to receive the wires of all electrical companies. It was to be entirely independent and to accept all as tenants on equal terms. It was organized under special act of the legislature to construct and maintain electrical subways in accordance with the terms of a contract entered into between the company and the city,- a contract which provides that when the net annual profits after paying expenses of maintenance and operation "shall exceed Io per cent. upon the actual cash capital invested" then "the excess of such profit over the Io per cent. shall be paid into the treasury of the city of New York." Another stipulation in the contract is that after January, 1897, the city through its Commissioners of the Sinking Fund may acquire the electrical subways by paying the actual cost thereof, and in case the earnings have not amounted to Io per cent. per annum a further payment is to be made in addition to the cost not to exceed Io per cent. on such cost. The company is required to keep full books and accounts and to file annual statements of costs, earnings and expenses with the Comptroller. At first the Consolidated Telegraph and Electrical Subway Company provided space in its subways for electrical conductors of all kinds. Later, the Empire City Subway Company was organized by like act and under similar contract with the city for the purpose of providing space for low tension and signal wires. The Consolidated Telegraph and Electrical Subway Company is owned by the Edison Company, the electrical combination covering the borough of Manhattan, which company is in turn owned by the Consolidated Gas Company which is under control of the Standard Oil interests. The Empire City Subway Company is owned or controlled by the New York (Bell) Telephone Company. As long as the Edison Company owns the Consolidated Telegraph and Electrical Subway Company no competitor of that company will be able to sell and distribute electric current on the Island of Manhattan. As long as the Bell Telephone Company owns the 
Empire City Subway Company effective obstacles will be interposed in the installation of the plant of any corporation that conflicts with the Bell Telephone, the Western Union Telegraph, their subsidiaries or allies. Interference with the present status of these two subway companies therefore involves the active opposition of the most powerful financial interests in this country.

The annual statements showing cost of construction and income which the Consolidated Telegraph and Electrical Subway Company and the Empire City Subway Company have filed since their organization display an evident intent to defraud. If they are able to mislead the city as to the actual cost of construction a greater sum must be paid to acquire the property and a larger proportion of the annual profits may be retained before Io per cent. is reached, the point where the city shares in the earnings. Moreover, the city has an interest only in the net earnings. Cost of maintenance and operation is to be deducted before net earnings are arrived at, and consequently the companies have an incentive to pile up running expenses. Before the suits previously referred to were commenced the books of the companies were examined. The construction account, according to the books of the Consolidated Telegraph and Electrical Subway Company in January, I903, amounted to $\$ 7,492$,291.62. The construction account is, however, charged with $\$ 1,875$,$\infty 00$, the face value of the total outstanding issue of capital stock, while the actual cash received by the company for the sale of the stock was only $\$ 40,000$. There were other items equally improper to include in a construction account which, according to contract, was limited to actual cash invested. The statement showing the cost to be seven and a half millions was as a matter of fact inflated to the extent of three millions. The Enıpire City Subway Company, the younger sister of the Consolidated Company, appeared also an adept bookkeeper. The Empire Company reported its gross earnings for I902 at $\$ 839,204.77$; operating expenses and maintenance, $\$ 350,441$; net earnings, $\$ 503,762.84$. It also came out that this Company in I884 entered into contracts with two other companies for keeping in repair its subways. Under such sub-contracts for maintenance during the year 1902 there was paid the sum of $\$ 224,210$. This is more per mile of subway than it costs per mile to maintain an average western railroad. Of course, the actual cost to maintain a permanent underground structure like an electrical subway is trifling. The 
bookkeeping of the two electrical subway companies affords an example of private corporate management. The two companies are in the hands of leading financiers and business methods should surely prevail. Nevertheless, the books have been kept in a way to defraud the city with which they have contracted, and agreements have been made to divert earnings from their own stockholders.

Municipal bookkeeping is often criticised and condemned, but it would be hard to find a parallel in the books of any municipality to the sworn statements of officers of the subway companies filed with the comptroller of the city of New York.

When Colonel McClellan assumed office on January I, I904, there were twelve months of unsettled bills, no existing contracts for city lighting and some inconvenient litigation. But the monopoly was in the hands of friends and Tammany recognizes its obligations. Those interested on either side patiently awaited the outcome. It was a long wait. For eight months matters remained in statu quo. At last, in October a year ago, the deadlock was broken and the commissioner in charge abjectly surrendered to the monopoly. Tammany had kept faith and had done its utmost to pay its political debt. But an injunction prevented the settlement from being immediately carried out. Public indignation rose. There was a change all along the line and Mayor McClellan promptly assumed the position occupied by his predecessor. Commissioner Oakley's action was, however, so unaccountable that the state legislature determined to take a hand and named a committtee to investigate the whole subject.

The Legislative Committee found a "gross abuse of legal privilege in over-capitalization and in the manipulation of securities, for the purpose of unifying control and eliminating all possible competition" and also "the investment of millions in securities earning no dividends and intrinsically worthless solely for the purpose of securing monopoly of control." The committee further reported that the Consolidated Telegraph and Electrical Subway Company had violated both the letter and the spirit of its contract with the city. The committee also questioned the validity of franchises and doubted the extent to which the companies are entitled to use the streets of the city.

The important recommendations made by the committee were for (a) the creation of a state commission to supervise gas and elec- 
tric companies; $(b)$ the reduction of the price of gas to consumers from a dollar to seventy-five cents per thousand cubic feet; $(c)$ the reduction in price of electric current to ten cents per kilowatt hour, and $(d)$ the reduction of the price of street arc lamps from $\$ 146$ to $\$ 100$ per lamp per year. The committee upon submitting their report introduced bills in accordance with their recommendations. The main fight was made on the price of gas to general consumers. The test of strength came in the end on a bill for eighty cent gas. The lobby won after a close vote. Senator McCarren, the head of the Democratic organization in Brooklyn, delivered his forces in a body; Mr. Murphy, the leader of Tammany Hall, allowed his representatives to be picked up one by one as needed. The Democratic mercenaries supplemented the vote of bolting up-state Republicans whose constituencies are not affected by public opinion in the city of New York and who can always act against the interest of the city without fear of just retribution.

The bill reducing the price of electric current became law. The Edison Company now advertises to its customers that prices have been reduced thirty-three and a third per cent. The maximum price for gas sold to the city for public purposes was fixed at seventyfive cents per thousand cubic feet. The price was formerly ninety cents. Street arc lamps were brought down from \$I46 to \$IOo per lamp per year. As far as street lighting is concerned, the prices now fixed by the legislature are substantially what were offered to the lighting companies during the Low administration and contemptuously declined by the corporations. In addition a state lighting commission has been brought into existence and the price of gas to general consumers throughout the city will undoubtedly be lowered. Plans have been prepared for a municipal electric plant for lighting the streets and public buildings and the real estate has already been purchased upon which to erect the necessary power houses.

The I905 election has been significant in New York as elsewhere and it is not likely that proceedings to acquire the electrical subways will be longer halted. Action may also be taken looking to the erection of municipal gas plants. However, the public will not be satisfied until every franchise has been examined into and its restrictions and limitations noted and enforced. Three years ago New York was at the mercy of a monopoly and to all appearances did not 
care. Public sentiment has been effectively aroused by the way it has been defied and disregarded and now it seems that the city intends to be master of the situation.

\section{Street Railways.}

In I884, after repeated effort lasting over thirty years, Jacob Sharp succeeded in obtaining control of New York's main highway, and Sharp and his associates were given a perpetual franchise to operate surface cars on Broadway. Sharp did not live long enough to pay the penalty exacted for the methods he had employed or personally to benefit from the grant, never afterwards overthrown, which he had obtained. But what Sharp filched from the public fell into able hands. About the celebrated Broadway franchise have been joined earlier and later grants for less important though necessary thoroughfares until there has developed a surface railway system under one management extending over the boroughs of Manhattan and The Bronx. The consolidation of surface lines in these two boroughs is, however, in competition with a combination of elevated and underground roads and in the subway development which has but commenced the city will gain by reason of the fact that two powerful rivals are competing for local transportation. The underground will also come in competition in Brooklyn where the elevated and surface roads have been brought together under one control. Perpetual franchises and the fact that franchises that might be redeemed are too costly for the city to buy back relieve the existing elevated and surface roads from danger of invasion of their immediate field by municipal lines; but the title to land beneath the surface has not yet been parted with and the community at large has even at this late day opportunity to benefit to the utmost in the direction and control of further underground construction. 